\title{
POTENSI TANNIN PADA RAMUAN NGINANG SEBAGAI INSEKTISIDA NABATI YANG RAMAH LINGKUNGAN
}

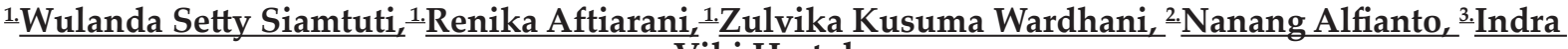 \\ Viki Hartoko, \\ 1.Fakultas Keguruan dan Ilmu Pendidikan, Universitas Muhammadiyah Surakarta \\ 2.Fakultas Farmasi, Universitas Muhammadiyah Surakarta \\ 3.Fakultas Teknik, Universitas Muhammadiyah Surakarta \\ Email: wulandasetty@gmail.com
}

\begin{abstract}
Abstrack-Tannin is a molecular compound that produced by plants and acts as an antinutrient and enzyme inhibitor, resulting in low starch hydrolysis and decreasing response to blood sugar on animals. Tannin active substance has potential to be used as a plant-based insecticide. There are several types of plants or plants that can produce tannins, including betel nut plants, acacia plants, cork, mangroves, pine and gambier. Gambier is commonly used by the society of Indonesia for nginang activities. The ingredients in nginang include betel, tobacco, gambier and whiting. In order to develop organic farming / eco-friendly organic insecticides are highly potential for use because they are safe for humans and livestock and also be natural preservatives as well as selectively controlling plant-disturbing organisms in food plants that are already immune to synthetic chemicals. The purpose of this program is to create an innovative organic pesticide that made from nginang ingredients as the main ingredient by the name of INSEKDUBANG (Insecticide Idu Abang). Determination of tannin total equivalent tannic acid using test method in the form of Spektrofotometri.
\end{abstract}

Keywords: tannin, organic insecticide, insekdubang

Abstrak-Tannin merupakan senyawa molekul yang dihasilkam oleh tanaman dan berperan sebagai penolak nutrisi (antinutrient) dan penghambat enzim (enzyme inhibitor) sehingga mengakibatkan rendahnya hidrolisis pati dan menurunkan respons terhadap gula darah pada hewan. Zat aktif tannin potensial digunakan sebagai insektisida nabati. Ada beberapa jenis tumbuh-tumbuhan atau tanaman yang dapat menghasilkan tannin, antara lain tanaman pinang, tanaman akasia, gabus, bakau, pinus dan gambir. Gambir biasa digunakan oleh masyarakat Indonesia untuk kegiatan nginang. Bahan-bahan pada nginang antara lain sirih, tembakau, gambir dan kapur sirih. Dalam rangka mengembangkan pertanian organik/ramah lingkungan insektsida organik sangat berpotensi untuk digunakan sebab aman untuk manusia dan binatang ternak dan dapat juga sebagai bahan pengawet alami serta selektif mengendalikan organisme pengganggu tanaman pada tanaman pangan yang sudah kebal terhadap bahan kimia sintetis. Tujuan program ini untuk menciptakan sebuah inovasi pestisida organik yang terbuat dari bahan ramuan nginang sebagai bahan utama dengan nama INSEKDUBANG (Insektisida Idu Abang). Penetapan tannin total equivalent tannic acid menggunakan metode uji berupa Spektrofotometri.

Kata Kunci: tannin, insektisida organik, insekdubang

\section{PENDAHULUAN}

Tanaman sayuran sebagai salah satu bahan kelengkapan makanan pokok manfaatnya sangat besar sebagai sumber gizi yang berhubungan langsung dengan kesehatan. Namun, sering kali tanaman pertanian yang sedang dalam masa tanam harus gagal panen akibat serangan hama serangga. Upaya pengendalian hama atau mikroorganisme penggangu tanaman dilakukan pada tanaman pangan, baik tanaman padi, holtikultura, maupun tanaman perkebunan dengan menggunakan pestisida sintetik.

Penggunaan pestisida merupakan salah satu cara yang terbukti mampu meningkatkan produksi hasil tanaman pangan untuk memenuhi kebutuhan 
makanan penduduk yang semakin meningkat terutama di negara berkembang. Namun, pestisida merupakan bahan kimia beracun yang apabila digunakan berlebihan akan berbahaya. Residu bahan kimia yang ditinggalkan dapat menjadi sumber pencemar bagi bahan pangan, air dan lingkungan hidup (Komisi Pestisida, 1997).

Hasil pertanian yang beredar di Indonesia, baik yang berasal dari dalam negeri maupun luar negeri tidak boleh mengandung residu pestisida melebihi batas yang ditetapkan. Namun, regulasi ini belum mengatur multi-residu pestisida yang umumnya digunakan selama brcocok tanam. Sementara dalam Peraturan Menteri Pertanian No. 27 Tahun 2009 tentang pengawasan keamanan pangan terhadap pemasukan dan pengeluaran pangan segar asal tumbuhan hanya mengatur multi-residu pestisida pada buah dan sereal. Batas maksimum residu (Maximum Residue Limits) dari ratusan jenis pestisida pada tanaman pangan telah diberlakukan di negara Uni Eropa dan Jepang. Beberapa jenis produk pertanian Indonesia pernah ditolak oleh Jepang karena kontaminasi residu pestisida sehingga perlu perbaikan proses produksi pertanian dan pengembangan sistem pengukuran multi residu pestisida secara kromatografi (Tampubolon, 2013).

Mengingat banyaknya dampak negatif yang ditimbulkan akibat penggunana pestisida sintetik, maka perlu dicari komponen pengendalian hama terpadu (PHT) yang dinilai aman, efektif, dan murah untuk menyusun pengelolaan Organisme Pengganggu Tanaman (OPT) pada tanaman pertanian. Dalam masalah ini perlu dilakukan upaya pengendalian yang lebih bijaksana seperti pemakaian insektisida nabati. Zat aktif yang berpotensi digunakan sebagai insektisida nabati diantaranya seperti alkaloid, terpenoid, fenolik, tannin dan zat-zat kimia sekunder lainnya yang dapat berpengaruh terhadap sistem saraf atau otot, keseimbangan hormon, reproduksi, perilaku seperti penolak, penarik, anti-makan (antifeeding), dan sistem pernafasan (Setyawaty, 2002). Tannin merupakan senyawa makro molekul yang dihasilkan oleh tanaman dan berperan sebagai penolak nutrisi (antinutrient) dan penghambat enzim (enzyme inhibitor) sehingga mengakibatkan rendahnya hidrolisis pati dan menurunkan respons terhadap gula darah pada hewan (Matsushita et al., 2002). Sejalan dengan pendapat Mardiana (2009), bahwa senyawa tannin adalah senyawa fenolik yang merupakan polimerasi polifenol sederhana. Senyawa ini ditemukan hampir didalam dua grup, yakni tannin yang dapat dihidrolisis dan tannin kondensasi. Zat ini umumnya digunakan untuk menurunkan kadar glukosa darah dengan cara memacu metabolisme glukosa dan lemak, sebagai antiseptic, obat luka bakar, sebagai penawar racun pada kasus keracunan alkaloid, dapatmenghentikan pendarahan kecil dan menghentikan diare. Selain itu, penggunaan senyawa tannin dapat menyebabkan terjadinya penyerapan air pada tubuh organisme sehingga dapatmematikanorganisme, karenatubuh organisme kekurangan air.

Senyawa tannin ini bisa ditemukan pada tumbuhan gambir dan sirih. Gambir dan sirih biasa digunakan oleh masyarakat pada aktivitas nginang. Nginang adalah istilah untuk mengunyah sirih dalam bahasa Jawa yang memerlukan bahan-bahan lain sebagai "ramuannya". Perlengkapan atau "bumbu" untuk menyiapkan sirih pinang ini secara umum terdiri atas daun sirih, pinang, kapur (basah/mentah atau kering), gambir, dan tembakau. Ada 
juga yang menambahkan kapulaga ke dalam ramuan ini. Semua bahan tersebut kemudian dibungkus dengan daun sirih. Tembakau biasa dipakai di bagian akhir setelah selesai mengunyah kinang tersebut. Di daerah lain, ada yang nginang tanpa mengkonsumsi tembakau.

\section{Sirih Hijau (Piper betle, L)}

Daun sirih dikunyah bersama pinang, kapur sirih, dan tembakau (kadang disertai dengan perasan jeruk nipis) yang menimbulkan sensasi ringan dan perasaan tubuh lebih sehat. Mengunyah daun sirih menghasilkan warna merah pada air liur. Daun sirih mengandung minyak atsiri $0,8-1,8 \%$ (terdiri atas khavikol, chavibetol (betel phenol), allylpyrocatechol (hydroxychavikol), allylpyrocatechol-mono dan -diatcetate, karvakrol, eugenol, eugenol methylether, p-cymene, cineole, caryophyllene, cadinene, estragol, terpenena, seskuiterpena, fenil propana, tannin, diatase, karoten, tiamin, riboflavin, asam nikotinat, vitamin C, gula, pati, dan asam amino. Chavikol yang menyebabkan sirih berbau khas dan memiliki khasiat antibakteri (daya bunuh bakteri lima kali lebih kuat daripada fenol biasa) serta imunomodulator (Dalimartha, 2006).

Antibakteri pada fenol daun sirih sangat efektif untuk mengurangi bahkan menekan pertumbuhan bakteri tanaman. $\mathrm{H}$ al tersebut dibuktikan pada hasil penelitian Rumahlewang (2011), yang menunjukkan bahwa buah sirih (Piper betle, L), memiliki kandungan fenol yang khas dan disebut betel fenol atau aseptol, khavikol, gula dan tannin, yang diduga mampu menekan pertumbuhan bakteri Xanthomonas campestris pv. campestris. Selain itu, biji sirih juga memilki kandungan eugenol yang dapat bersifat toksik terhadap bakteri, kemungkinan hal ini disebabkan oleh senyawa-senyawa tersebut yang bekerja secara sinergis atau dengan yang lain dalam menekan pertumbuhan bakteri Xanthomonas Campestris pv. Campestris sehingga bakteri tidak mampu berkembang dengan baik karena dihambat oleh minyak yaitu eugenol yang menyebar dalam media. Ini menunjukkan bahwa eugenol mampu untuk menekan pertumbuhan bakteri karena eugenol berbau sangat menyengat dan terasa pedas.

\section{Gambir (Uncaria gambir, Roxb)}

Gambir merupakan produk dari tanaman gambir (Uncaria gambir, Roxb) mengandung senyawa fungsional yang termasuk dalam golongan senyawa polifenol. Senyawa polifenol dalam gambir terutama adalah katekin (Heyne, 1987). Sejalan dengan pendapat Zeijlstra (1943), komponen utama gambir adalah catechin (asam catechin atau asam catechu) dan asam catechin tannat (catechin anhydrid). Gambir juga sedikit mengandung quercetine, yaitu bahan pewarna yang memiliki warna kuning. Catechin bila mengalami pemanasan cukup lama atau pemanasan dengan larutan bersifat basa dengan mudah akan menjadi catechin tannat karena kondensasi sendiri dan menjadi mudah larut dalam air dingin atau air panas.

Senyawa polifenol dalam gambir memiliki khasiat antibakteri. Pernyataan tersebut dibuktikan pada hasil penelitian Pambayun (2007), yang menunjukkan bahwa sifat antibakteri dari ekstrak produk gambir yang diperoleh dengan berbagai pelarut dan dinyatakan dalam diameter daya hambat (DDH) terhadap bakteri uji Gram-negatif dan bakteri uji Gram-positif. Dalam ekstrak produk gambir senyawa fenol total merupakan komponen terpenting terkait dengan sifat antibakteri. Oleh karena itu, dapat direkomendasikan bahwa ekstraksi menggunakan etil asetat pada produk gambir menghasilkan ekstrak yang paling 
besar daya hambatnya pada bakteri Gram-positif.

\section{Kapur Sirih $\left(\mathrm{CaCO}_{3}\right)$}

Kapur sirih memiliki kandungan kalsium karena mempunyai rumus CaCO3.Secaraumum, kalsiummerupakan mineral yang amat penting bagi manusia terutama sebagai pembentuk tulang. Kapur sirih bisa digunakan sebagai obat bersamaan dengan bahan lain, seperti untuk mengatasi batuk selesma, gusi bengkak, bisul, masalah haid, digigit serangga serta penyakit kulit misalnya panu, kurap, dan kutil (Nurnabila, 2011).

Rendaman air kapur sirih sangat efektif dilakukan sebagai pengendalian hama pada padi sawah karena selain dapat menetralkan tanah asam, kapur juga dapat dijadikan sebagai pupuk untuk menambah unsur kalsium yang berkurang akibat panen, erosi serta untuk menggemburkan tanah. Hal tersebut dibuktikan pada hasil penelitian Handayani (2013), yang menunjukkan bahwa ternyata bahan nabati yang diuji dapat digunakan untuk mengendalian keong mas dengan sifat daya kerja yang berbeda. Interaksi antara rendaman kapur sirih dengan ekstrak daun ubi karet berpengaruh nyata terhadap mortalitas keong mas (Pomacea canaliculata Lamarck) pada perlakuan selama 24, 48, dan 72 jam. Perbedaan konsentrasi dan jenis senyawa dapat memberikan pengaruh berbeda terhadap penghambatan aktivitas makan hama. Proses kematian hama akan semakin cepat dengan pertambahan konsentrasi yang digunakan.

\section{Tembakau (Nicotinana tobacum, Linn)}

Nikotin dihasilkan dari akar tanaman dan selanjutnya didistribusikan di daun melalui batang, dalam bentuk murni merupakan cairan yang tidak berwarna, rasa pahit dan pedas, mudah larut dalam air dan pelarut organik. Tembakau mengandung bahan aktif golongan alkaloid seperti anobarin, anatobine, myosine, nicotinoid, nicotelline, nicotyrine, norcotine dan pirolidine, yang dapat bertahan selama seminggu.

Ekstrak tembakau mampu digunakan sebagai larvasida, sejalan dengan hasil penelitian Susanti (2012), bahwa tumbuhan zodia dan tembakau efektif digunakan sebagai pengendali jentik Aedes aegypti. Ekstrak zodia lebih baik dalam membunuh jentik Aedes aegypti. Konsentrasi minimal dari ekstrak zodiac maupun ekstrak tembakau yang dapat membunuh jentik Aedes aegypti adalah $1,56 \%$.

Hasil penelitian Listiyati (2012), menunjukkan bahwa, hasil maserasi daun tembakau seberat $1 \mathrm{~kg}$ menghasilkan 100,7 ml maserasi tembakau. Untuk penyemprotan ke nyamuk dilakukan sebanyak 3 kali penyemprotan dengan konsentrasi 90\%. Penyemprotan I : efektivitas $86,9 \%$ Penyemprotan II : efektivitas $100 \%$ Penyemprotan III : efektivitas 100\%. Hal ini pun bisa dipercobakan untuk serangga lain. Kandungan bahan kimia dalam tanaman tersebut menunjukkan bioaktivitas pada serangga, sepertibahan penolak (repellent), penghambat makan (antifeedant), penghambat perkembangan serangga (insect growth regulator), dan penghambat peneluran (oviposition deterrent).

\section{METODE PENELITIAN}

\section{ProduksI}

Waktu pelaksanaan produksi dan pengujian INSEKDUBANG selama 3 bulan, yaitu pada bulan Mei-Juli 2016. Pelaksanaan proses produksi INSEKDUBANG di Jl. Ahmad Yani 130 RT. 03/06 Kartasura, Kartasura, Sukoharjo, Jawa Tengah 57167 .

Alat yang digunakan dalam proses produksi adalah: 
Bioeksperimen

Volume 3 No.2, (September 2017)

ISSN 2460-1365

Tabel 1. Alat produksi

\begin{tabular}{lcc}
\hline \multicolumn{1}{c}{ Alat } & Volume & Satuan \\
\hline Blender & 2 & Buah \\
$\begin{array}{l}\text { Timbangan digital } \\
\text { kapasitas 5 kg }\end{array}$ & 1 & Buah \\
Gelas takaran 1 liter & 2 & Buah \\
Pengaduk kayu & 2 & Buah \\
Drum plastik 100 liter & 1 & Buah \\
Saringan alumunium & 2 & Buah \\
Saringan kasa/halus & 2 & Buah \\
Ember 20 liter & 2 & Buah \\
Pisau tanggung & 2 & Buah \\
Aquarium power liquid & 1 & Buah \\
filter & 1 & Buah \\
Botol air mineral 20 liter & 1 & Buah \\
Air pump & 1 & Buah \\
Gayung air & 2 & Buah \\
Baskom plastic & &
\end{tabular}

Bahan yang digunakan dalam proses produksi INSEKDUBANG adalah sebagai berikut:

Tabel 2. Bahan Pendukung

\begin{tabular}{lccc}
\hline Jenis Bahan & Volume & Satuan & \% \\
\hline Sirih Hijau & 1 & $\mathrm{Kg}$ & 4,32 \\
Gambir & 1 & Ons & 0,432 \\
Kapur Sirih/ & 1 & Ons & 0,432 \\
Enjet & & & \\
Tembakau Su- & $1 / 2$ & $\mathrm{Kg}$ & 2,16 \\
sur & & & \\
Tetes & 1 & Liter & 6,26 \\
Air Mineral & 20 & Liter & 86,39 \\
Botol 250 ml & 80 & Buah & - \\
Stiker & 80 & Lembar & - \\
\hline
\end{tabular}

Proses produksi INSEKDUBANG dilakukan melalui beberapa tahap agar dapat menghasilkan sebuah produk yang berkualitas, diantaranya:

\section{a. Persiapan}

Mempersiapakan alat dan bahan yang dibutuhkan yaitu blender, baskom, pengaduk, timbangan, takaran gelas, drum sedang, sirih hijau, gambir, kapur sirih, dan tembakau kering

\section{b. Pencampuran}

\section{Bagan 1. Proses pencampuran}
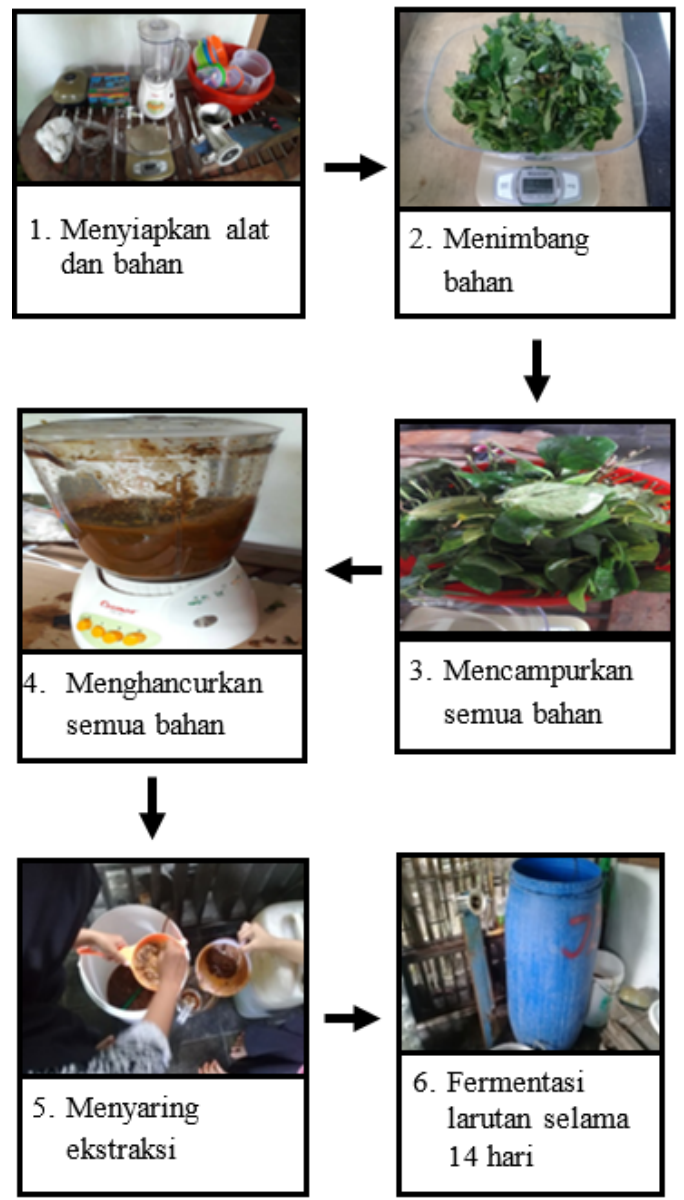

\section{c. Pencetakan}

Memasukkan hasil tersebut kedalam kemasan dan ditutup rapat.

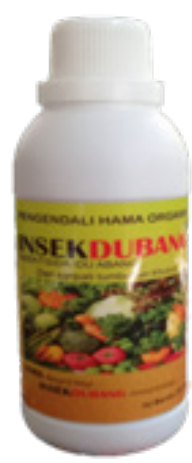

Gambar 1. Produk INSEKDUBANG 


\section{Pengujian Kandungan}

Pengujian kandungan INSEK-

DUBANG dilakukan di Laboratorium

Penelitian dan Pengujian Terpadu Universitas Gajah Mada Jl. Kaliurang Km 4 Sekip Utara Yogyakarta. Berupa uji kualitatif kuantitatif dengan metode spektrofotometri untuk mengetahui jenis zat aktif dan kadar zat aktif yang ada pada 85 gram INSEKDUBANG yang telah diubah menjadi bentuk padatan dengan parameter berupa alkaloid, tannin dan minyak atsiri dalam dua kali ulangan.

\section{HASIL DAN PEMBAHASAN}

1. Penetapan Tannin Total Equivalent Tannic Acid Metode Spektrofotometri

Metode penetapan Tannin ini melalui beberapa tahap, yaitu: mengekstraksi $0,1 \mathrm{~g}$ sampel dengan $10 \mathrm{ml}$ dietil eter selama 20 jam, kemudian menyaring dan meresidu yang diperoleh, kemudian mendidihkan dengan $10 \mathrm{ml}$ aquades selama 2 jam, kemudian mendinginkan dan menyaring. Menambahkan ekstrak yang diperoleh dengan aquades hingga volume ekstrak 5 ml. Menambahkan $1 \mathrm{ml}$ ekstrak dengan $0,1 \mathrm{ml}$ reagen Folin Ciocalteu dan divortex, menambahkan dengan $2 \mathrm{ml}$ Natrium Carbonat 20\% dan divortex lagi. Menambahkan dengan aquades hingga volume $5 \mathrm{ml}$. Membaca absorbansi pada $\lambda 760 \mathrm{~nm}$ setelah menginkubasi selama 30 menit pada suhu kamar (Chanwitheesuk, 2004).

\section{Penetapan Kurva Baku Standar}

Penetapan kurva baku standar ini melalui beberapa tahap, yaitu: menimbang dengan seksama standar asam tanat, menambahkan dengan 0,1 $\mathrm{ml}$ reagen Folin Ciocalteu dan divortex, menambahkan dengan $2 \mathrm{ml}$ Natrium Carbonat $20 \%$ dan divortexlagi, kemudian menambahkan dengan aquades hingga volume $5 \mathrm{ml}$, membaca absorbansi pada $\lambda 760 \mathrm{~nm}$ setelah menginkubasi selama 30 menit pada suhu kamar. Membuat larutan stok, menambahkan sebanyak 5 $\mathrm{ml}$ pipet larutan standar dengan aquades. Mengencerkan sesuai tabel pengenceran. Berat standar tannic acid: 0,0100 g.

Pada uji kandungan tannin pada sampel INSEKDUBANG dengan metode uji Spektrofotometri diperoleh hasil sebagai berikut:

Tabel 3. Tabel Pengenceran Standar Quinine

\begin{tabular}{lcccccc}
\hline Conc & 3,125 & 6,25 & 12,5 & 25 & 50 & Ppm \\
\hline Lart Induk & 312,5 & 625 & 1250 & 2500 & 5000 & $\mu \mathrm{l}$ \\
\hline Chloroform & 9987,5 & 9375 & 8750 & 7500 & 5000 & $\mu \mathrm{l}$ \\
\hline Volume & 10 & 10 & 10 & 10 & 10 & $\mathrm{Ml}$ \\
\hline
\end{tabular}

Tabel 4. Kadar Tannin Equivalent Tannic Acid metode Spektrofotometri

\begin{tabular}{|c|c|c|c|c|c|c|c|}
\hline Sampel & Replikasi & $\begin{array}{l}\text { Berat } \\
\text { Sampel } \\
\text { (g) }\end{array}$ & $\begin{array}{l}\text { FP } \\
(\mathrm{x})\end{array}$ & $\begin{array}{l}\text { Volume } \\
\text { add (ml) }\end{array}$ & $\begin{array}{c}\text { Hasil } \\
\text { pembacaan } \\
(\mathrm{ppm})\end{array}$ & $\begin{array}{c}\text { Total Tannin } \\
\text { Equivalent } \\
\text { Tannic Acid } \\
(\% \text { b/b) }\end{array}$ & $\begin{array}{l}\text { Rata- } \\
\text { rata } \\
(\% \mathrm{~b} / \mathrm{b})\end{array}$ \\
\hline \multirow{2}{*}{ INSEKDUBANG } & 1 & 0,1004 & 10 & 100 & 68,109 & 67,84 & \multirow{2}{*}{67,65} \\
\hline & 2 & 0,1009 & 10 & 100 & 68,071 & 67,46 & \\
\hline
\end{tabular}


Senyawa tannin adalah senyawa astringent yang memiliki rasa pahit dari gugus polifenolnya yang dapat mengikat dan mengendapkan atau menyusutkan protein. Zat astringent dari tannin menyebabkan rasa kering dan puckery (kerutan) di dalam mulut setelah mengkonsumsi teh pekat, anggur merah atau buah yang mentah. Dekstruksi atau modifikasi tannin selama ini berperan penting dalam pengawet kayu, adsorben logam berat, obat-obatan, antimikroba dll. Tannin merupakan senyawa phenol yang larut dalam air dan memiliki berat molekul antara 500 dan 3000 Da. Tannin diklasifikasikan menjadi hydrolyzable tannin dan condensed tannins (proanthocyanidins).

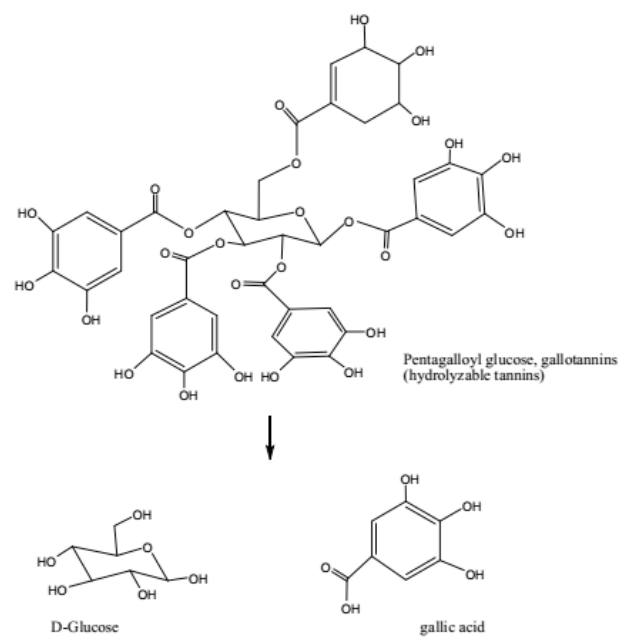

Gambar 2. Struktur gallotannins (Hagerman, 2002)

\section{Hydrolyzable Tannin}

Struktur molekul hydrolyzable tannin di tengah-tengahnya memiliki gugus karbohidrat (biasanya D-glukosa) merupakan hidroksil dari karbohidrat atau phenolic esterified seperti asam gallat (dalam gallotannins) atau asam ellagat (dalam ellagitannins). Hydrolyzable tannin yang dihidrolisis oleh asam lemah atau basa lemah menghasilkan karbohidrat dan asam phenolik. Contoh gallotannins adalah ester asam gallic glukosa dalam asam tannic $\left(\mathrm{C}_{76} \mathrm{H}_{52} \mathrm{O}_{46}\right)$, ditemukan dalam daun dan kulit di banyak spesies tanaman.

\section{Condensed Tannins}

Condensed tannins dikenal sebagai proanthocyanidins merupakan polimer yang terdiri dari 2 sampai 50 (atau lebih) unit flavonoid yang bergabung dengan ikatan karbon-karbon, yang tidak rentan terhadap hidrolisis. Tannin terkondensasi adalah produk polimerisasi flavan-3ols dan flavan-3,4-diol atau campuran dari dua polimer, yang disebut sebagai "flavans" (Salunkhe, Chavan, \& Kadan, 1989; Sanderson et al., 2001 ).

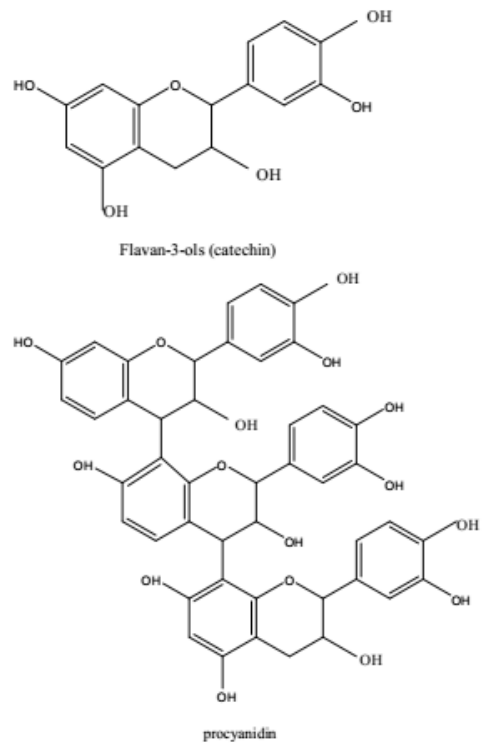

Gambar 3. Struktur catechin dan procyanidin (Hagerman, 2002)

Beberapa kegunaan tannin antara lain sebagai pelindung pada tumbuhan pada saat masa pertumbuhan bagian tertentu pada tanaman, sebagai anti hama bagi tanaman sehingga mencegah serangan fungi, digunakan dalam proses metabolisme pada bagian tertentu tanaman sejalan dengan hasil penelitian yang telah dilakukan (Iwan, 2002) untuk pengujian tersebut diperoleh hasil yaitu bahan pengawet kayu dengan tannin 
dapat meningkatkan ketahanan kayu terhadap serangan rayap kayu kering.

\section{Penentuan Total Alkaloid}

Metode penentuan total alkaloid ini melalui beberapa tahap, yaitu: menimbang sampel dengan seksama, menambahkan $5 \mathrm{ml} \mathrm{HCl} 2 \mathrm{~N}$, mengocok kemudian menyaring. Mencuci larutan dengan $10 \mathrm{ml}$ larutan chloroform sebanyak 3 kali dalam corong pisah, menetralkan larutan dengan menambahkan $0,1 \mathrm{~N}$ $\mathrm{NaOH}$, menambahkan $5 \mathrm{ml}$ larutan BCG dan $5 \mathrm{ml}$ buffer fosfat, kemudian menambahkan larutan chloroform $5 \mathrm{ml}$, mengaduk dengan magnetic stirrer selama 15 menit dengan kecepatan $500 \mathrm{rpm}$, mengulangi ekstraksi dengan chloroform sebanyak 2 kali. Mengumpulkan fase chloroform, mengevaporasi dengan gas nitrogen. Setelah itu, menambahkan $10 \mathrm{ml}$ chloroform pada labu ukur 10 $\mathrm{ml}$, kemudian membaca serapan pada panjang gelombang $470 \mathrm{~nm}$, kemudian membuat kurva baku standar dengan menimbang standar quinine sebanyak $10 \mathrm{mg}$. Dari hasil pengujian $85 \mathrm{~g}$ sampel INSEKDUBANG, diperoleh hasil kadar alkaloid sebagai berikut:

Tabel 5. Tabel Pengenceran Standar Quinine

\begin{tabular}{ccccccccc}
\hline Conc & 6,25 & 12,5 & 25 & 50 & 100 & 200 & 400 & Ppm \\
\hline Lart Induk & 31,25 & 62,5 & 125 & 250 & 500 & 1000 & 2000 & $\mu 1$ \\
\hline Chloroform & 4968,75 & 4937,5 & 4875 & 4750 & 4500 & 4000 & 3000 & $\mu l$ \\
\hline
\end{tabular}

Tabel 6. Total alkaloid equivalent quinine

\begin{tabular}{|c|c|c|c|c|c|c|c|}
\hline Sampel & Replikasi & $\begin{array}{c}\text { Berat } \\
\text { Sampel } \\
\text { (g) }\end{array}$ & $\begin{array}{l}\text { FP } \\
(\mathbf{x})\end{array}$ & $\begin{array}{l}\text { Volume } \\
\text { add (ml) }\end{array}$ & $\begin{array}{c}\text { Hasil } \\
\text { pembacaan } \\
(\text { ppm) }\end{array}$ & $\begin{array}{c}\text { Total Tannin } \\
\text { Equivalent } \\
\text { Tannic Acid } \\
(\% \text { b/b }) \\
\end{array}$ & $\begin{array}{c}\text { Rata- } \\
\text { rata } \\
(\% \mathbf{b} / \mathbf{b})\end{array}$ \\
\hline \multirow{2}{*}{ INSEKDUBANG } & 1 & 0,1052 & 1 & 10 & 147,031 & 1,40 & \multirow{2}{*}{1,43} \\
\hline & 2 & 0,1020 & 1 & 10 & 148,784 & 1,46 & \\
\hline
\end{tabular}

Beberapa kelompok alkaloid diantaranya adalah benzyl isoquinon, seperti paverin, berberin, tubokuranin dan morfm. Alkoloid dapat berfungsi sebagai larvasida botani. Alkaloid dengan struktur indol, dikelompokkan sebagai alkaloid indol seperti strikhnin dan quinine yang terasa pahit dan merupakan senyawa yang berfungsi repelen bagi serangga. Alkoloid purin terdiri dari berbagai jenis alkaloid yang merupakan derivat dari asam nikotinat, purin, asam antranilat, poliasetat, dan terpenes.

Penggunaan bahan-bahan yang berasal dari tumbuhan dapat digunakan sebagai salah satu alternatif penggunaan insektisida kimia yang sering disebut pestisida nabati atau bioinsektisida.
Pestisida nabati mengandung senyawa bioaktif sepeti alkaloid, terpenoid, fenolik dan zat-zat kimia sekunder lainnya yang dapat berpengaruh terhadap sistem saraf atau otot, keseimbangan hormon, reproduksi, perilaku seperti penolak, penarik, anti-makan (antifeeding) dan sistem pernafasan (Setyawaty, 2002). Daun sirih (Piper betle L.) termasuk dalam famili piperaceae (sirih-sirihan) yang mengandung minyak atsiri dan senyawa alkaloid (Nugroho, 2003). Alkaloid yang terkandung dalam daun sirih (Piper betle L.) adalah arecoline.

\section{Penetapan kadar minyak atsiri}

Metode penetapan kadar minyak atsiri ini melalui beberapa tahap, yaitu: 
menimbang sampel dengan seksama, memasukkan sampel ke dalam labu, menambahkan aquades $500 \mathrm{ml}$, menambahkan batu didih, memasangkan pada rangkaian alat destilasi stahl, mengisi buret buret dengan aquades hingga penuh, memanaskan selama 4 jam setelah mendidih, setelah penyulingan selesai membiarkan selama 1 jam, menghitung volume minyak atsiri pada buret.

Tabel 8. Kadar minyak atsiri

\begin{tabular}{|c|c|c|c|c|c|}
\hline Sampel & Replikasi & $\begin{array}{c}\text { Berat } \\
\text { Sampel (g) }\end{array}$ & $\begin{array}{c}\text { Volume } \\
\text { sampel (ml) }\end{array}$ & $\begin{array}{c}\text { Kadar Minyak } \\
(\% \mathrm{~b} / \mathrm{b})\end{array}$ & $\begin{array}{c}\text { Kadar rata-rata } \\
(\% \mathrm{~b} / \mathrm{b})\end{array}$ \\
\hline \multirow{2}{*}{ INSEKDUBANG } & 1 & 5,00 & 0,01 & 0,2 & \multirow{2}{*}{0,2} \\
\hline & 2 & 5,00 & 0,01 & 0,2 & \\
\hline
\end{tabular}

Minyak atsiri merupakan minyak yang mudah menguap dan mengandung aroma atau wangi yang khas (Sastroamidjojo, 1988). Minyak atsiri dari daun sirih mengandung 30\% fenol dan beberapa derivatnya. Kavikol merupakan komponen paling banyak dalam minyak atsiri yang memberi bau khas pada sirih.

Menurut Maryani (2004), sirih merupakan tanaman yang dikenal merupakan tanaman yang tingginya mencapai $15 \mathrm{~m}$. Daun berbentuk jantung, jika diremas mempunyai aroma sedap. Bagian tanaman yang digunakan adalah daunnya. Daun sirih mengandung minyak atsiri sebanyak $4 \%$ (hidroksi kavikol, kavikol, kavibetol, estragol, eugenol, metil eugenol, karvakrol, terpen, dan seskuiterpen), tannin, diastae, gula, dan pati.Kandunganminyakatsirinyamemiliki daya membunuh kuman (bakteriosid), fungi, dan jamur. Sejalan dengan pendapat Dalimartha (2008), bahwa rasa sirih pedas, bersifat hangat, astringen, aromatik, dan stimulan. Chavikol yang menyebabkan sirih berbau khas dan memiliki khasiat antibakteri (daya bunuh bakteri lima kali lebih kuat daripada fenol biasa) serta imunomodulator.

\section{SIMPULAN DAN SARAN}

\section{Simpulan}

Bahan ramuan nginang yang berupa sirih, tembakau, gambir dan kapur sirih berpotensi digunakan sebagai bahan dasar pembuatan insektisida nabati yang ramah lingkungan karena mengandung senyawa kimia berupa tannin sebesar $67,65 \%$, alkaloid sebesar $1,43 \%$ dan minyak atsiri sebesar $0,2 \%$. Senyawa tersebut dapat menurunkan intensitas penyakit pertanian seperti wereng, walang sangit, dll dengan cara menghambat pertumbuhan serangga dewasa maupun larvanya.

\section{Saran}

Setelah adanya pemaparan tentang kandungan INSEKDUBANG serta uji laboratorium kandungan zat kimianya, disarankan produk INSEKDUBANG yang sudah dibuat untuk ditindaklanjuti sebagai penelitian yang menginginkan produk INSEKDUBANG tersebut.

\section{UCAPAN TERIMAKASIH}

Terimakasih kepada Ristek Dikti atas didanainya program usaha kami dalam Program Kreativitas Mahasiswa Kewirausahaan 2017, kepada Universitas Muhammadiyah Surakarta yang telah memfasilitasi dalam pelaksanaan program usaha kami dalam Program Kreativitas Mahasiswa Kewirausahaan 2017 dan pihak-pihak yang telah membantu terlaksananya program ini 
DAFTAR PUSTAKA

Dalimartha, S. (2008). Atlas Tumbuhan Obat Indonesia Jilid 4. Jakarta: Puspa Swara, Anggota Ikapi.

Hagerman, A.E. (2002). Tannin Chemistry. Miami University, Oxford, USA.

Handayani, D. (2013). “Uji Efektivitas Pengendalian Keong Mas (Pomacea canaliculata Lamark) pada Padi Sawah dengan Menggunakan Rendaman Air Kapur Sirih (CaCO3) dan Ekstrak Daun Ubi Karet (Manihot glaziovii M. A)". Jurnal EduBio Tropika. 1(2). 61-120.

Heyne, K. (1987). Tumbuhan Berguna Indonesia. Jilid II. Diterjemahkan oleh Badan Litbang Kehutanan, Jakarta. Yayasan Sarana Wana Jaya, Jakarta.

Iwan R. (2002), Tannin, Fakultas Pertanian JurusanIlmu Kehutanan, Universitas Sumatera Utara.

Listiyati, A. K., Nurkalis, U., Sudiyanti, \& Hestiningsih, R. (2012).

Ekstraksi Nikotin dari Daun Tembakau (Nicotina Tabacum) dan Pemanfaatannya Sebagai Insektisida Nabati Pembunuh Aedes sp." Jurnal Ilmiah Mahasiswa. 2(2). 67-70.

Mardiana, Lina. (2009). Mencegah dan Mengobati Kanker pada Wanita dengan Tanaman Obat. Jakarta: Penebar Swadaya.

Maryani, H. dan Lusi, K. (2004). Tanaman Obat untuk Influenza. Tangerang: Agromedia Pustaka.

Matsumura, F. (1985). Toxicology of Insecticides, $2^{\text {nd }}$ Edition. New York: Plenum Press.

Matsushita, H.; T. Mio \& O. Haruko (2002). Porcine Pancreatic $\alpha$-amylase Shows binding activity toward N-linked Oligosaccharides of Glycoproteins. The Journal of Biological Chemistry, $277,4680-4686$
Nurnabila, Nida. (2011). "Formulasi Tablet Hisap Ekstrak Etanol Sirih (Piper betle, L.) Dan Kapur Sirih $\left(\mathrm{CaCO}_{3}\right)$ Dengan Mikrokristalin Selulosa (Avicel) sebagai Pengikat serta Pengaruhnya Terhadap Kadar CD4 dalam Darah". Skripsi. Jurusan Farmasi Fakultas Kedokteran dan Ilmu Kesehatan Universitas Negeri Syarif Hidayatullah.

Pambayun, R. dkk. (2007). " Kandungan Fenol dan Sifat Antibakteri dari berbagai Jenis Ekstrak Produk Gambir (Uncaria gambir Roxb)". Majalah Farmasi Indonesia. 18(3). 141146.

Rumahlewang, Filhemina. (2011). "Efektifitas Extrak Buah Sirih Sebagai Pestisida Botanis terhadap Xanthomonas campestris pv. Campestris". Jurnal Agroforestri. 6(2). 109-113.

Salunkhe, D., Chavan, J., \& Kadan, S. (1989). Nutritional Consequence of dietary Tannins in "Dietary Tannins": Consequents and Remedies. Boca Raton, FL: CRC Press. p. 113.

Sanderson, G., Ranadive, A., Eisenburg, L., Farrel, F., Simons, R., Manley, C., et al. (2001). "Contribution of Polyphynolic Compounds to the taste of tea, Sulfur and Nitrogen compound in food flavors. In G. Charalambous, I. Katz (Eds.)". Acs symposium series (Vol. 26, p. 14). Washington, DC: American Chemical Society.

Sastroamidjojo, S., (1988). Obat Asli Indonesia, Jakarta: Penerbit Dian Rakyat.

Susanti, L. Dan Boesri, H. (2012). "Toksisitas Biolarvasida Ekstrak Tembakau Dibandingkan dengan Ekstrak Zodia terhadap Jentik 
Vektor Demam Berdarah Dengue (Aedes aegypti)". Bulan Penelitian Kesehatan. 40(2). 75-84.

Tampubolon, B. D. dkk. (2013). Pertanian Standar dan Penilaian Kesesuaian. Jakarta: Indeks.
Zeijlstra, F. Z. N. (1943). “Sirih, Pinang en Gambier. Dalam C. J.J. Van Hall en C. Van de Koppel (Eds.). Landbouw in Indische Archipel, W. Van Hoeve's, Gravenhage". Majalah Farmasi Indonesia. 18(3). 141-146. 